\title{
Knowledge and Practices of Nurses Regarding Spread of Nosocomial Infection Ingovernment Hospitals, Lahore
}

\author{
Maria Jahangir, Muhammad Ali, Muhammad Shahid Riaz
}

\begin{abstract}
INTRODUCTION: Nosocomial infection, also called hospital acquired infection occur in patient who are admitted in Hospital for a long or short period of time for some therapeutic or diagnostic purposes yet patient have no evidence of infection before admission in hospital. The pathogenic organism of nosocomial infection may be bacterial, viral, contagious and parasitic those are found in the air, within utensils; may spread from one person to another person.

OBJECTIVES: The objective of this study was to evaluate the knowledge and practices of nurses regarding the spread of nosocomial infection in government hospitals of Lahore.

DESIGN: A cross sectional Descriptive study was conducted in Government hospitals of Lahore, Pakistan from February 2016 to April 2016. Sample size was 240 and the response of the participants were taken through simple random sampling techniques. Data was analyzed by using SPSS version 21.

RESULTS: Most of the participants were female $231(96.3 \%)$ and $9(3.8 \%)$ were male. It is revealed that nurses have enough knowledge about spread of nosocomial infection as out of 240 participants 77 $(32.1 \%)$ were agree and $69(28.8 \%)$ were strongly agree that they are fully aware of hand washing guidelines but their practices to reduce the spread of nosocomial infection were not good as $81(33.8 \%)$ were neutral and $72(30.0 \%)$ were disagree that they follow the recommended guidelines for use of alcohol based solutions or other antiseptics before and after each contact to move or during the transferring of the patients.

CONCLUSION: Nurses had good knowledge about spread of hospital acquired infection, use of safety precautions, uses of alcohol based formulations but their practices to reduce the spread of nosocomial infection were not up to satisfactory level.
\end{abstract}

KEY WORD: Knowledge, Practice, Spread, Nosocomial Infection

This article may be cited as: Jahangir M, Ali M, Riaz MS. Knowledge and Practices of Nurses Regarding Spread of Nosocomial Infection Ingovernment Hospitals, Lahore. J Liaquat Uni Med Health Sci. 2017;16(03):149-53. doi: 10.22442/jlumhs.171630524

\section{INTRODUCTION}

Nosocomial infection, also called hospital acquired infection occur in patient who are admitted in Hospital for a long or short period of time for some therapeutic or diagnostic purposes yet patient have no evidence of infection before admission in hospital ${ }^{1}$. Patients have no sign and symptoms of nosocomial infection before hospitalization, however when remain hospitalized for some time comes in contact with beds, linens and utensils that has been contaminated by the others patients and their attendants and acquire nosocomial infection. The causative organism of nosocomial infection may be bacterial, viral, parasites that are found in the air and in the utensils and can spread from one person to another person ${ }^{2}$. The prevalence of nosocomial infection in developed countries is much lower than developing countries, studies shows it is 15.5 per 100 patients in Europe and USA. In Intensive care units prevalence rate was 47.9 per 1000 patients. The most common infection was surgical site infection that was 5.6 per 100 surgical procedures ${ }^{3}$. Nosocomial infection have a great impact on the health of hundreds of millions people and it is considered a major global issue today by all the stakeholders. Picture is gloomier in developing countries, where it affects more than $25 \%$ to $30 \%$ patients that are admitted in health care settings. World Health Organization must play its role in this part of the world to ensure safe and hygienic environment.

Every infection requires a medium for its transmission, nurses, caregiver to patients can be affected themselves and may also serve as a source of spread particularly when attending patients without using standard antiseptic protocol. When standard hygienic guidelines developed to minimize the risk of spread of the infection are avoided the chances of hospital 
acquired infections are greater ${ }^{4}$. To have a positive impact upon the health of the every patient in hospital, it is very important for all nurses to have enough knowledge of hospital acquired infection, and to observe standard practices so that the spread of the nosocomial infection in any health care setting can be prevented $^{5}$. The ultimate consequence of hospital acquired infection is prolonged hospitalization. This is the prime responsibility of the health care provider to ensure safe environment for the patients and therefore all health care professionals involved in providing patient care should be well trained regarding the control and prevention of hospital acquired infection ${ }^{6}$. Published studies shows remarkable difference in the prevalence of nosocomial infection between developed and developing countries. It is $15.5 \%$ in developing countries as compared to $7.1 \%$ in Europe and $4.5 \%$ in USA ${ }^{2}$. The ventilator dependent patients are more vulnerable for hospital acquires infection where contaminated instrument may be the source. The recent report of International Nosocomial infection control Consortium 2007-2012 indicated that ventilator related pneumonia is 15 times higher and catheter related infection was four times higher in developing countries ${ }^{7}$.

Nurses are at risk of acquiring and transmitting hospital acquired infections while delivering nursing care; therefore, they should have sufficient knowledge and practice to control and prevent spread of nosocomial infection. Use of standard precautions to prevent patients from nosocomial infection is important part of nursing care. It has been suggested that health care workers should have satisfactory knowledge level regarding spread of transmissible diseases ${ }^{8}$.

A study from Kenya revealed that the $100 \%$ participants practiced hand hygiene; $87.8 \%$ by using water and soap while $12.2 \%$ of the participants reported that they used alcohol based hand rub during hand hygiene. However, when observed for practice, a lower proportion (16.7\%) of the participants performed hand hygiene before doing a procedure. A larger proportion (100\%) performed hand hygiene after contact with some infected materials, for example after emptying a catheter bag. This shows that nurses are more worried about their lives than those of patients ${ }^{1}$.

Use of standard precautions is the key to combat and minimize the occurrence of hospital acquired infection it is necessary for all health care providers and nurses to follow guidelines because they have more exposure to patients when providing nursing care and other procedures. Nurses' knowledge and practices have great impact over control and prevention of hospital acquired infection ${ }^{6}$.

\section{METHODOLOGY}

A cross sectional descriptive study was conducted to assess the knowledge and practices of nurses regarding spread of nosocomial infection in Government hospitals, Lahore from February 2016 to April 2016. The target population for this study was staff nurses of government hospitals in Lahore with sample size of 240. Simple random sampling technique was used to collect data. 5 point Likert scale questionnaire adopted from the article "Exploring Knowledge, Attitudes and Practices of Registered Nurses Regarding the Spread of Nosocomial Infections" by Eunice W. Kamunge was used to collect data. Questionnaire consists of three sections, section A for demographic data, section B having 10 questions on Likert scale from strongly agree to strongly disagree to assess the knowledge, while section $C$ include 14 questions regarding the practices of nurses regarding spread of nosocomial infection. This questionnaire takes approximately 10 minutes to complete.

All staff nurses were given opportunity to be included in current study except those having 1 year or less clinical experience. To conduct the current study permission was obtained from the Ethics Review Committee, University of Lahore. Other ethical issues observed were pledge of confidentiality and secrecy of the participants. All participants were voluntarily participated with reassurance that personal data will be confidential and data will be presented anonymously. SPSS version 21 was used for Descriptive statistics and analysis of the data.

\section{RESULTS}

The majority of the participants were females $n=231$ $(96.3 \%)$ as compared to male $n=9(3.8 \%)$. Among 240 respondents, $104(43.3 \%)$ belongs to $21-30$ age group, $80(33.3 \%)$ respondents belongs to $31-40$ and $56(23.3 \%)$ were belongs to $41-50$ age group. 160 participants $(66.7 \%)$ were having general nursing diploma, $77(32.1 \%)$ were BSN POST RN and 3 (1.3\%) participants were BSN generic.

\section{Variable Analysis}


Maria Jahangir, Muhammad Ali, Muhammad Shahid Riaz

TABLE I: KNOWLEDGE OF NURSES' REGARDING SPREAD OF NOSOCOMIAL INFECTION

\begin{tabular}{|c|l|c|c|c|c|c|}
\hline S\# & \multicolumn{1}{|c|}{ Question } & $\begin{array}{c}\text { Strongly } \\
\text { disagree } \\
\mathbf{n}(\%)\end{array}$ & $\begin{array}{c}\text { Disagree } \\
\mathbf{n}(\%)\end{array}$ & $\begin{array}{c}\text { Neutral } \\
\mathbf{n}(\%)\end{array}$ & $\begin{array}{c}\text { Agree } \\
\mathbf{n}(\%)\end{array}$ & $\begin{array}{c}\text { Strongly } \\
\text { agree } \\
\mathbf{n}(\%)\end{array}$ \\
\hline 01 & $\begin{array}{l}\text { Do you think that Nosocomial infections may be } \\
\text { transmitted via medical equipment such as } \\
\text { syringes, thermometers, needles, catheters, } \\
\text { stethoscopes etc? }\end{array}$ & $4(1.7 \%)$ & $17(7.1 \%)$ & $36(15.0 \%)$ & $95(39.6 \%)$ & $88(36.7 \%)$ \\
\hline 02 & $\begin{array}{l}\text { Do you agree that Neutropenic patients or } \\
\text { those with communicable diseases (e.g. } \\
\text { diseases of the respiratory system) should be } \\
\text { kept in private rooms? }\end{array}$ & $7(2.9 \%)$ & $16(6.7 \%)$ & $51(21.3 \%)$ & $102(42.5 \%)$ & $64(26.7 \%)$ \\
\hline 03 & $\begin{array}{l}\text { Do you agree that Hand hygiene should be } \\
\text { performed after removing sterile or non-sterile } \\
\text { gloves? }\end{array}$ & $2(.8 \%)$ & $19(7.9 \%)$ & $82(34.2 \%)$ & $95(39.6 \%)$ & $42(17.5 \%)$ \\
\hline 04 & $\begin{array}{l}\text { Do you agree that Nosocomial infections are } \\
\text { mainly caused by bacteria brought into the } \\
\text { hospital by hospital workers? }\end{array}$ & $14(5.8 \%)$ & $45(18.8 \%)$ & $75(31.3 \%)$ & $81(33.8 \%)$ & $25(10.4 \%)$ \\
\hline 05 & $\begin{array}{l}\text { This necessary to wash or disinfect hands } \\
\text { before and after each patient contact. }\end{array}$ & $24(10.0 \%)$ & $63(26.3 \%)$ & $72(30.0 \%)$ & $71(29.6 \%)$ & $10(4.2 \%)$ \\
\hline 06 & $\begin{array}{l}\text { I wash hands or rub with alcohol before per- } \\
\text { forming simple surgery and caring for wounds, } \\
\text { in patients with normal immune systems. }\end{array}$ & $4(1.7 \%)$ & $22(9.2 \%)$ & $66(27.5 \%)$ & $108(45.0 \%)$ & $40(16.7 \%)$ \\
\hline
\end{tabular}

TABLE II: PRACTICES OF NURSES' REGARDING SPREAD OF NOSOCOMIAL INFECTION

\begin{tabular}{|c|c|c|c|c|c|c|}
\hline S\# & Question & $\begin{array}{c}\text { Strongly } \\
\text { disagree } \\
\text { n (\%) }\end{array}$ & $\begin{array}{l}\text { Disagree } \\
\text { n (\%) }\end{array}$ & $\begin{array}{l}\text { Neutral } \\
\text { n (\%) }\end{array}$ & $\begin{array}{l}\text { Agree } \\
\text { n (\%) }\end{array}$ & $\begin{array}{l}\text { Strongly } \\
\text { agree } \\
\mathrm{n}(\%)\end{array}$ \\
\hline 01 & $\begin{array}{l}\text { Did you follow the recommended guidelines for } \\
\text { use of alcohol based solutions or other } \\
\text { antiseptics before opening vascular access } \\
\text { equipment? }\end{array}$ & $2(.8 \%)$ & $26(10.8 \%)$ & $61(25.4 \%)$ & $103(42.9 \%)$ & $48(20.0 \%)$ \\
\hline 02 & $\begin{array}{l}\text { Did you wash your hands or rub with alcohol } \\
\text { based solution or other antiseptics before and } \\
\text { after providing a nursing procedure? }\end{array}$ & $11(4.6 \%)$ & $26(10.8 \%)$ & $30(12.5 \%)$ & $114(47.5 \%)$ & $59(24.6 \%)$ \\
\hline 03 & $\begin{array}{l}\text { Did you wash your hands before and after } \\
\text { having direct contact with patient's intact skin? }\end{array}$ & $4(1.7 \%)$ & $52(21.7 \%)$ & $68(28.3 \%)$ & $82(34.2 \%)$ & $34(14.2 \%)$ \\
\hline 04 & $\begin{array}{l}\text { Did you wash your hands when moving from a } \\
\text { contaminated body site to a clean-body site } \\
\text { during patient care? }\end{array}$ & $3(1.3 \%)$ & $19(7.9 \%)$ & $17(7.1 \%)$ & $104(43.3 \%)$ & $97(40.4 \%)$ \\
\hline 05 & $\begin{array}{l}\text { Did you occasionally polish your fingernails or } \\
\text { wear artificial nails. }\end{array}$ & $35(14.6 \%)$ & $88(36.7 \%)$ & $66(27.5 \%)$ & $47(19.6 \%)$ & $4(1.7 \%)$ \\
\hline 06 & $\begin{array}{l}\text { I am less compliant with recommended } \\
\text { guidelines for reducing transmission of NI when } \\
\text { workload increases or in emergencies }\end{array}$ & $8(3.3 \%)$ & $50(20.8 \%)$ & $68(28.3 \%)$ & $102(42.5 \%)$ & $12(5.0 \%)$ \\
\hline 07 & $\begin{array}{l}\text { Did you wash your hands after touching } \\
\text { inanimate surfaces and objects in patient's } \\
\text { surroundings? }\end{array}$ & $12(5.0 \%)$ & $63(26.3 \%)$ & $93(38.8 \%)$ & $69(28.8 \%)$ & $3(1.3 \%)$ \\
\hline 08 & $\begin{array}{l}\text { Did you remove your rings, watch or bracelet } \\
\text { before beginning hand hygiene? }\end{array}$ & $30(12.5 \%)$ & $103(42.9 \%)$ & $44(18.3 \%)$ & $45(18.8 \%)$ & $18(7.5 \%)$ \\
\hline
\end{tabular}




\section{DISCUSSION}

The purpose of the study was to assess the knowledge and practices of nurses about spread of nosocomial infection in hospitals, The demographic finding of this study was that out of 240 participants females nurses were in majority $n=231(96.3 \%)$ when compared to male $n=9(3.8 \%)$. Nurses' knowledge about spread of nosocomial infection was adequate. Out of 240 participants $77(32.1 \%)$ were agree that they are fully aware of hand washing guidelines and $69(28.8 \%)$ were strongly agree about awareness of hand washing guidelines.

These study findings were also supported by the findings of Kamunge ${ }^{6}$ who found that out of 352 respondents $318(90.3 \%)$ were fully aware of hand washing guidelines. This is also revealed from this study that nurses also had good knowledge about safety precautions as 95(39.6\%) were agree and 88 $(36.7 \%)$ were strongly agree about safety precautions. Okechukwu et al has also showed that $77.5 \%$ respondents had good knowledge about the use of safety precautions ${ }^{10}$. In a national study ${ }^{11}$ it has also been shown that the spread of hospital acquired infections can adequately be controlled by observing safety precaution and hand hygiene.

This portrayed form the findings of the study that nurses had good knowledge about the use of alcohol based formulations as 114(47.5\%) were agree and 59 $(24.6 \%)$ were strongly agree about it. These study findings were supported by Kamunge who found that $347(98.65)$ respondents were knowledgeable about alcohol based formulations ${ }^{6}$.

The study findings showed that in spite of having good knowledge about spread of nosocomial infection practices of nurses to reduce the spread of hospital acquired infection were not adequate enough to provide safe patient care as the findings of the study showed that only $49(20.4 \%)$ were agree and 72 (30.05) were disagree that they follow the recommended guidelines for use of alcohol based solutions or other antiseptics before and after each patient contact. These finding are not supported with literature because nurses should have sufficient practice about control and prevention of infection from one patient to another patient and these practices should applied to every patient if patient has an infectious disease or not ${ }^{12}$.

The findings of this study revealed that out of 240 respondents 126(52.5\%) were agree and 58(24.2\%) were strongly agree that they wash hands before and after inserting urinary catheters. It was also supported by another study findings that revealed that prevention of nosocomial infection, it is necessary to change the practices of health care providers about infection control practices and hand hygiene ${ }^{13}$.

\section{CONCLUSION}

We conclude that nurses had enough knowledge about hospital acquired infections, risk factors for its transmission and the recommended hand washing guidelines for reducing the spread of nosocomial infection but their practices to reduce the spread of nosocomial infection, use of recommended hand washing guidelines are inadequate.

\section{RECOMMENDATIONS}

- Hospital management team should facilitate the provision of all infection control equipments so that nurses could provide safe nursing care to all patients and prevent them from nosocomial infection.

- Hospital management should arrange different seminars and workshops to update the knowledge and practices of nurses about control and prevention of hospital acquired infection.

\section{REFERENCES}

1. Moyo GM. Factors influencing compliance with infection prevention standard precautions among nurses working at Mbagathi district hospital, Nairobi, Kenya (Doctoral dissertation, University of Nairobi) 2013.

2. Revelas A. Healthcare-associated infections: a public health problem. Niger Med J 2012, Apr 1;53 (2):59-64.

3. Allegranzi B, Bagheri Nejad S, Combescure C, Graafmans W, Attar H, Donaldson L, et al. Burden of endemic health-care-associated infection in developing countries: systematic review and meta -analysis. Lancet 2011 Jan 15;377(9761):228-41.

4. Abdulraheem IS, Olapipo AR, Amodu MO. Primary health care services in Nigeria: Critical issues and strategies for enhancing the use by the rural communities. J Public Health Epidemiol. 2012; 4(1):5-13.

5. Ehsani SR, Cheraghi MA, Nejati A, Salari A, Esmaeilpoor AH, Nejad EM. Medication errors of nurses in the emergency department. J Med Ethics Hist Med. 2013; 6:11.

6. Kamunge EW, Cahill T, Zipp G, Parasher R. Exploring Knowledge, Attitudes and Practices of Registered Nurses Regarding the Spread of Nosocomial Infections. Antimicrob Resist Infect Control 2015; 4(suppl 1):P60.

7. Rosenthal VD, Maki DG, Mehta Y, Leblebicioglu $\mathrm{H}$, Memish ZA, Al-Mousa $\mathrm{HH}$, et al. International Nosocomial Infection Control Consortium (INICC) report, data summary of 43 countries for 20072012. Device-associated module. Am J Infect Control. 2014; 42(9):942-56. 
8. Eskander HG, Morsy WY, Elfeky HA. Intensive Care Nurses' Knowledge \& Practices regarding Infection Control Standard Precautions at a Selected Egyptian Cancer Hospital. J Educ Pract. 2013; 4(19):160-74.

9. Okechukwu EF, Motshedisi C. Knowledge and practice of standard precautions in public health facilities in Abuja, Nigeria. Int J Infect Control. 2012; 8(3):1-7.

10. Devrajani BR, Shah SZ, Devrajani T, Qureshi GA. Nosocomial infections in medical ward (Four months descriptive study in a tertiary care hospital). World J Med Sci. 2009; 4(1):13-7.

11. Siegel JD, Rhinehart E, Jackson M, Chiarello L, Health Care Infection Control Practices Advisory Committee. 2007 guideline for isolation precautions: preventing transmission of infectious agents in health care settings. Am J Infect control. 2007; 35(10)(suppl 2):S65-S164.

12. Bouallègue $O$, Naija $W$, Said $H$, Nouria $A$, Jaidane $N$, Dhidah L, et al. P233: Incidence of ICU acquired nososcomial infections in University Hospital of Sahloul (Sousse-Tunisia). Antimicrobial Resistance Infection Control. 2013; 2(suppl 1):P233.

13. Fashafsheh I, Ayed A, Eqtait F, Harazneh L. Knowledge and Practice of Nursing Staff towards Infection Control Measures in the Palestinian Hospitals. J Educ Practice. 2015; 6(4):79-90.

14. Pittet D, Allegranzi B, Storr J, Nejad SB, Dziekan G, Leotsakos A, et al. Infection control as a major World Health Organization priority for developing countries. J Hosp Infect. 2008; 68(4):285-92.

\begin{tabular}{|l|}
\hline \multicolumn{1}{|c|}{ AUTHOR AFFILIATION: } \\
Maria Jahangir (Corresponding Author) \\
The University of Lahore, Lahore-Pakistan. \\
Email: mariashaikh54321@gmail.com \\
Muhammad Ali \\
The University of Lahore, Lahore-Pakistan. \\
Muhammad Shahid Riaz \\
The University of Lahore, Lahore-Pakistan. \\
\hline
\end{tabular}

